\title{
REALITAS DAUGTHERHOOD DALAM NOVEL GADIS TANGSI KARYA SUPARTO BRATA
}

\author{
Ade Husnul Mawadah \\ Fakultas Sastra Universitas Sultan Ageng Tirtayasa \\ email: adehusnul@yahoo.com
}

\begin{abstract}
This study aims to describe the daugterhood reality in Gadis Tangsi, a novel by Suparto Brata. The reality covers two aspects, i.e. (a) a relation pattern between a mother and her daughter, and (b) the construction of the child character's identity in relation to the mother character. The data source was Gadis Tangsi, a novel by Suparto Brata. The data were collected through intensive reading and recording and were analyzed using the qualitative descriptive technique. The findings show that the dauhgterhood reality is apparent in the relation of Raminem - Teyi and that of Putri Parasi - Teyi. Teyi is a reflection of a young woman who tries to rebel against values in an army boarding house environment. She is much influenced by Raminem (her mother) and Putri Parasi. They directly form her identity. They inculcate ideology to make her a different girl from the rest in the environment. The relation between the mother and her daughter in this novel serves as a means of constructing Teyi's identity.
\end{abstract}

Keywords: daughterhood, identity construction, ideology

\section{PENDAHULUAN}

Sebagai salah satu genre sastra, novel di Indonesia mengalami pertumbuhan yang sangat pesat. Seiring dengan pertumbuhan itu, sejumlah sastrawan yang bergelut dalam penulisan novel semakin berusaha menunjukkan kemampuannya dalam menghadirkan novel-novel bermutu, yang dibuktikan dengan banyaknya pengarang yang mendapatkan penghargaan nasional maupun Internasional atas novelnya. Hal itu pun didukung oleh minat baca para penikmat sastra yang jumlahnya semakin meningkat.

Pertumbuhan yang sangat pesat dalam dunia sastra di Indonesia telah menarik perhatian sejumlah penerbit untuk menerbitkan karya sastra, terutama novel. Salah satu penerbit yang mulai melirik pasar pembaca sastra adalah Penerbit Buku Kompas. Diantara persaingan antarpenerbit, Penerbit Buku
Kompas berusaha menjaga mutu buku sastra yang diterbitkannya. Dari sejumlah buku sastra yang diterbitkannya, Penerbit Buku Kompas menerbitkan novel Gadis Tangsi karya Suparto Brata.

Gadis Tangsi adalah novel karya Suprapto Brata yang bercerita tentang seorang gadis bernama Teyi yang hidup di lingkungan tangsi pada masa kolonial Belanda. Teyi sendiri merupakan cerminan seorang perempuan muda yang mencoba memberontak terhadap nilai-nilai yang ada di lingkungan tangsi. Nilai-nilai yang serba longgar dalam menjalani hidup, termasuk dalam urusan seks.

Dalam usaha pemberontakan itu, Teyi sangat dipengaruhi oleh pola pikir tokoh Raminem (Ibu Teyi) dan tokoh Putri Parasi. Kedua tokoh tersebut secara langsung membentuk identitas Teyi. Tokoh Raminem yang terobsesi untuk menjadi kaya mendidik Teyi untuk 
menjadi perempuan yang mandiri, selalu bekerja keras, dan patuh pada orang tua. Melalui tokoh Putri Parasi, Teyi mendapatkan pengetahuan tentang kehidupan bangsawan. Putri Parasi mendidik Teyi untuk menjadi seperti putri keraton Solo yang adiluhung. Teyi diajarkan mengenai budaya Jawa, tata krama pergaulan, bahasa Jawa Kromo Inggil, dan bahasa Belanda. Pendidikan tersebut telah membentuk Teyi menjadi gadis tangsi yang elegan. Gadis tangsi yang juga dapat diterima oleh bangsa Belanda dan golongan bangsawan yang hidup di lingkungan tangsi.

Proses tersebut menggambarkan sebuah hubungan yang erat antara ibu dengan anak perempuannya. Hubungan antara Raminem dan Teyi sebagai ibu kandung, dan hubungan Putri Parasi dan Teyi sebagai guru, yang telah dianggapnya sebagai ibu kedua. Hubungan tersebut dikenal dengan istilah daugtherhood.

Kedua perempuan tersebut Raminem dan Putri Parasi menjadi tokoh yang sangat berpengaruh bagi pembentukan identitas tokoh Teyi. Oleh karena itu, pada penelitian ini, analisis hubungan antara ibu dengan anak perempuannya (daugtherhood) akan dilakukan terhadap hubungan antara tokoh Raminem-Teyi dan tokoh Putri Parasi-Teyi. Selain itu, penelitian ini juga membahas mengenai pengaruh ideologi kedua tokoh, Raminem dan Putri Parasi, dalam membangun konstruksi identitas tokoh Teyi sebagai perempuan tangsi.

Pemakaian istilah daugtherhood secara sederhana dapat diartikan sebagai hubungan antara anak perempuan dengan ibunya. Hubungan yang erat antara anak perempuan dengan ibunya ini secara jelas diungkapkan oleh Susan Koppelman, seorang penulis yang sekaligus bertindak sebagai editor dari buku terkenal, Between Mothers and Daughters: Stories Across a Generation (1985).

\section{METODE}

Sumber data penelitian adalah novel Gadis Tangsi karya Suprapto Brata. Dengan demikian data penelitian ini berupa data yang menyangkut fokus penelitian yaitu realitas daugtherhood dalam novel tersebut. Deskripsi verbal simbol-simbol kebahasaan yang menjelaskan adanya pemaparan realitas daugtherhood yang dijadikan data penelitian

Pemerolehan data penelitian dilakukan dengan dua cara yaitu pembacaan intensif dan pencatatan. Kegiatan pembacaan intensif dilakukan untuk menemukan realitas daugtherhood dalam novel Gadis Tangsi karya Suparto Brata. Kegiatan selanjutnya adalah melakukan pencatatan data-data verbal yang berkaitan fokus penelitian. Untuk memudahkan kegiatan analisis, kegiatan pencatatan dilakukan dengan menggunakan kartu-kartu data.

Analisis data dilakukan dengan teknik deskriptif kualitatif. Sesuai dengan permasalahan yang ada, analisis yang dilakukan berkaitan dengan dua aspek yaitu: (a) pola hubungan tokoh ibu dan anak, (b) konstruksi identitas tokoh anak dalam relasinya dengan tokoh ibu sebagai realisasi daugtherhood dalam novel Gadis Tangsi.

Dalam penelitian ini kesahihan yang digunakan adalah kesahihan yang berorientasi pada data yakni kesahihan semantik. Kesahihan semantis mengukur tingkat kesensitifan suatu teknik terhadap makna-makna simbolik yang relevan dengan konteks tertentu. Untuk mencapai derajat kehandalan, peneliti melakukan pembacaan berulang-ulang (intraratter). Dari pembacaan intensif dan berulang-ulang diharapkan dapat diperoleh hasil yang memenuhi kriteria kehandalan, dengan ditemukannya konsistensi data penelitian. 


\section{HASIL DAN PEMBAHASAN Hubungan Raminem dan Teyi}

Pada novel Gadis Tangsi, daugtherhood digambarkan melaluluihubungan antara Teyi dengan Raminem dan Teyi dengan Putri Parasi. Raminem sebagai ibu kandung Teyi dan Putri Parasi sebagai guru sekaligus ibu kedua bagi Teyi.

Tokoh Raminen adalah ibu kandung Teyi, seorang perempuan Jawa yang ikut suaminya, Wongsodirjo, bertugas di Deli, Sumatera. Raminem memiliki dendam masa lalu pada kakak iparnya, Yu Camik, yang menganggapnya sebagai perempuan desa yang miskin yang mau mejadi istri Wangsodirjo hanya karena ingin menikmati harta orang tua Wangsodirjo. Dendam itulah yang membuatnya terobsesi untuk menjadi orang kaya. Selama hidupnya di tangsi, ia membantu keuangan keluarga dengan berjualan pisang goreng setiap pagi, mengkreditkan barang, dan memutar uangnya untuk usaha pinjaman berbunga. Dalam usaha mencapai obsesinya itu, ia menarik Teyi untuk membantunya berjualan pisang goreng dan menagih kepada penduduk tangsi yang membeli barangnya secara kredit atau meminjam uangnya. Selain itu, Teyi juga harus membenahi bajan, anglo, arang, dan sisa tepung, serta mengasuh Tumpi, adiknya.

Sebagai ibu, Raminem termasuk sosok perempuan yang sangat menguasai hidup Teyi. Ia mengatur kapan Teyi harus bekerja dan kapan Teyi harus bermain. Teyi tidak memiliki kesempatan untuk melakukan apa yang ingin ia lakukan. Masa kanak-kanak Teyi habis untuk membantu ibunya berjualan pisang goreng keliling tangsi. Hal itu tergambar pada kutipan berikut ini.

"La,iya. Kamu ikut ke Simpang Lama."

"Untuk apa, Mbok?"Teyi takut rencananya menemui Ceplik gagal.
"Untuk menjejali perutmu biar kenyang! Sudahlah, disuruh orangtua jangan banyak mendebat!" ujar Raminem galak.

Teyi pun menyerah. Rencananya bermain dengan Ceplik pupus. Batal. Beban pekerjaan yang lain, yang enggan dilakukan oleh Teyi, telah disiapkan oleh Raminem. Ikut pergi ke Simpang Lama berarti menempuh perjalanan panjang dan melelahkan. Sebel! Tapi itu kemauan Simbok, jangan coba menolak! (hlm.7)

Raminem mengajarkan Teyiuntuk menjadi perempuan yang mandiri, tidak malas, dan selalu bekerja keras. Raminem membentuk Teyi menjadi anak tangsi yang berbeda dengan anakanak tangsi lainnya yang cenderung malas dan lebih suka bermain-main.

"Jangan bodoh, kamu. Simbokmu sekaranginiorangpandai!Perempuan tangsi lainnya tidak berbuat apaapa, aku bekerja keras dengan otak, dengan akal dengan kepandaian. Dari kepandaian kita meraih kekayaan. Dari kekayaan kita meraih kekuasaan! Akhirnya kita memiliki semua itu, kepandaian, kekayaan, kekuasaan. Asal urutannya begitu. Itu nanti akan kita raih semua kalau bapakmu sudah pensiun, pulang ke Tanah Jawa. Sekarang ini yang harus kita lakukan adalah bekerja keras! Modal orang pandai yang utama adalah bekerja keras!" (hlm.17)

Bekerja keras untuk mencapai kekayaan adalah hal yang selalu diucapkan Raminem pada Teyi. Dengan kekayaan, seseorang dapat meningkatkan derajatnya di mata orang lain. Teyi mengikuti apa kata Raminem, meskipun sebenarnya ia lebih senang bermain seperti anak-anak tangsi lainnya. Oleh karena itulah, seringkali Teyi mendebat Raminem tentang konsep hidupnya itu. Teyi menganggap ibunya sangat kejam karena sering melarangnya bermain bebas seperti teman-temannya. Kapan pun, teman-temannya bisa bermain, bermain apa saja tanpa harus mengasuh adiknya, sedangkan dirinya boleh 
bermain setelah pisang goreng yang dijajakannya habis. Itu pun harus dilakukan Teyi dengan mengajak serta adiknya. Semua yang dilakukan ibunya itu membuat Teyi merasa tidak disayangi.

Teyi telah menjadi budak ibunya untuk mencapai kekayaan. Ia harus menukar masa kanak-kanaknya dengan obsesi ibunya untuk mengejar harta kekayaan sebanyak-banyaknya. Tekanan dari ibunya membuatnya berani mendebat, meskipun pada akhirnya ia akan menuruti apa yang diminta ibunya. Hingga suatu hari, keinginannya untuk memberontak pada perintah ibunya muncul semakin besar. Ia berjalan jauh keluar tangsi. Tujuannya adalah minggat dari rumahnya. Minggat dari bayangbayang ibunya sebagai bentuk protes dari kekajaman ibunya selama ini. Ia ingin ibunya merasa kehilangan dirinya. Apa yang dilakukan Teyi menunjukkan bahwa ia ingin eksistensinya diakui oleh ibunya. Akan tetapi, usahanya itu tidak berhasil sempurna. Ia ditangkap polisi karena dikira akan mencuri barang di toko Cina.

Tragedi saat ia akan minggat dari rumahnya itu, ternyata menjadi awal terbukanya hubungan Teyi dengan orang Belanda dan golongan bangsawan di lingkungan tangsi. Sejak peristiwa itu, Teyi dianggap sebagai anak perempuan tangsi yang berani. Ia menjadi anak tangsi yang juga dikenal oleh orang Belanda dan golongan bangsawan yang menjadi pejabat di tangsi itu. Selain itu, ibunya menjadi lebih lunak dan Teyi pun mulai merasa anggapannya tentang ibu yang tidak menyayanginya adalah salah.

Selama masa pertumbuhannya menjadi perempuan dewasa, Teyi menjadi objek pemasukan ideologi Raminem. Teyi dibentuk untuk menjadi seorang perempuan yang sesuai dengan ideologinya. Perempuan yang kuat, mandiri, dan selalu bekerja keras mengejar kekayaan. Namun, tetap menjaga nilai-nilai "keperempuan"-nya dan bersikap tidak seperti perempuan tangsi lainnya, yang bebas dengan nilai-nilai yang longgar.

“Tentang Lik Urip selingkuh! Suka memuji-muji keelokan tubuh Yuk Sarumi. Lik Gemi cemburu berat! Lik Urip dikatakan mata keranjang! Anunya kecantol...!"

“Teyiiii! Jangan sekali-kali mengucapkan kata itu! Jelek! Perempuan tidak pantas menyebut kata itu, tahu!" (hlm.23)

Raminem selalu mengajarkan pada Teyi untuk menjaga sikapnya agar menjadi perempuan yang baik, perempuan yang selalu berada dalam aturan dan nilai-nilai "keperempuan"-nya.

\section{Hubungan Putri Parasi dan Teyi}

Gusti Bandara Raden Ajeng Kus Parasi Kusumastuti atau Putri Parasi adalah seorang putri keraton (kemenakan raja) Surakarta yang berpendidikan dan berwawasan luas. Ia mederita penyakit yang cukup parah, tak ada satu orang pun yang dapat mengobatinya, sehingga muncul pemikiran berdasarkan mitos di lingkungan keraton agar Putri Parasi segera menikah dengan laki-laki yang sederajat. Mereka percaya bahwa penyakit Putri Parasi itu akan sembuh setelah ia menikah.

Putri Parasi akhirnya menikah dengan Raden Sarjubehi, Wakil Komandan Garnisun Tangsi Lorong Belawan di Medan. Sejak Raden Sarjubehi bertugas di Medan, Putri Parasi berkeinginginan kuat untuk keluar dari keraton dan tinggal bersama suaminya di Medan. Hidup berumah tangga seperti layaknya suami-istri. Keinginan itu merupakan cita-citanya dahulu, hidup dengan keluarga sendiri, tanpa banyak bergantung dengan keluarganya. Ia bosan dengan kehidupan di keraton. Hal itu jugalah 
yang memicunya untuk menganjurkan suaminya berhenti menjadi abdi dalem dan bekerja di Tanah Gopermenan.

Selama hidup bersama suaminya di lingkungan tangsi Lorong Belawan Medan, Putri Parasi ditemani oleh pengasuhnya sejak kecil bernama Mbok Jah. Bersamanya, Putri Parsi memberikan pendidikan pada Teyi secara sembunyi-sembunyi agar tidak diketahui Raminem. Sejak saat itulah, Teyi merasa Putri Parasi adalah ibu kedua (ibu angkat) baginya.

Putri Parasi mendidik Teyi tanpa kekerasan sehingga Teyi dapat dengan cepat menerima apa yang diajarkan Putri Parasi. Putri Parasi mengajarkan mengenai etika perempuan bangsawan, mulai dari cara berpenampilan, bersikap, dan berbahasa kromo inggil. Selain itu, Putri Parasi juga mengajarkan bahasa Belanda pada Teyi.

Apa yang dilakukan Putri Parasi terhadap Teyi didukung oleh obsesinya untuk membentuk Teyi seperti perempuan bangsawan sehingga layak mendapatkan suami seorang bangsawan. Kehidupan rumah tanggganya yang tidak dikaruniai seorang anak pun menjadi faktor pendukung upayanya memberikan pendidikan informal pada Teyi. Apa yang dilakukan Teyi menunjukkan bahwa ia ingin eksistensinya diakui oleh masyarakat di lingkungannya.

\section{Konstruksi Identitas Tokoh Teyi}

Identitas individu dalam interaksi sosial menjadi sesuatu yang fundamental dalam setiap interaksi sosial. Pertanyaan tentang diri sendiri, jati diri dapat menentukan bentuk interaksi sosialnya. Pada dasarnya setiap individu memiliki hasrat yang besar untuk membentuk identitas sosial yang positif terhadap dirinya (Susetyo, 2001:2). Hal tersebut merupakan kerangka untuk mendapatkan pengakuan (recognition) dari pihak lain dan persamaan sosial (social equality).

Hogg dan Abram (Susetyo, 2001: 3) mengatakan bahwa bagi setiap individu selalu ada upaya-upaya untuk mempertahankan identitas sosial yang positif yang memperbaiki citra jika ternyata identitas sosialnya sedang terpuruk, dalam skala individual maupun skala kelompok. Dalam konteks makro sosial, upaya mencapai identitas sosial yang positif dapat dicapai melalui dua cara, yaitu mobilitas sosial dan perubahan sosial. Mobilitas sosial adalah perpindahan individu dari kelompok yang lebih rendah ke kelompok yang lebih tinggi. Mobilitas sosial hanya mungkin terjadi jika peluang untuk berpindah itu cukup terbuka.

Konsep di atas dapat diaplikasikan pada tokoh Teyi dalam Gadis Tangsi. Ia berusaha untuk bangkit dari keterpurukan identitas individunya sebagai gadis jawa dari kalangan menengah ke bawah. Ia merasa sangat terpuruk ketika dicurigai hendak mencuri miniatur boneka mirip noni Belanda di sebuah toko milik orang Jepun, kemudian diserahkan kepada polisi. Sejak peristiwa itu, terbentuk keinginan di hatinya untuk membuktikan pada pemilik toko itu bahwa dia juga layak mereka layani dengan baik dan mampu membeli boneka miniatur itu. Terwujudnya keinginan tersebut cukup tinggi karena peluang Teyi sangat besar.

Teyi mendapatkan pendidikan dari Raminem untuk menjadi perempuan berani, mandiri, dan tidak malas mencari uang. Salah satu bentuk pendidikannya itu dilakukan dengan menyuruh Teyi menjajakan pisang goreng keliling tangsi. Hal itu ternyata membuka peluang lebih besar bagi Teyi untuk meningkatkan derajatnya. Teyi berkesempatan untuk beinteraksi langsung dengan Putri Parasi yang kemudian 
mengajarinya tentang tata krama perempuan bangsawan dan membuka cakrawalanya untuk memahami bahasa Belanda.

Teyi berhasil melakukan mobilitas sosial terhadap dirinya sendiri. Setelah ia bisa merubah image tentang dirinya, bersama Putri Parasi, ia dilayani dengan baik oleh pemilik toko tersebut. Dengan kebaya, kain, dan sanggul yang menunjukkan citra perempuan kelas menengah ke atas, ditambah lagi degan bahasa pengantar bahasa Belanda, Teyi diperlakukan dengan baik, berbeda ketika dia datang ke toko itu beberapa tahun lalu. Dalam studi sosiologi, Teyi dapat dikatakan sebagai individu yang belah melakukan mobilitas secara vertikal ke atas, yaitu mengangkat derajat sosialnya pada kelas sosial yang lebih tinggi.

Putri Parasi merupakan agent of change bagi Teyi. Ia membuka cakrawala Teyi tentang kehidupan kelas atas,yaitu kehidupan bangsawan yang mendapat posisi yang baik di kalangan bangsa Belanda. Teyi menjadi perempuan yang lemah lembut dan kalem sehingga banyak laki-laki yang takjub padanya. Mereka memandang Teyi sebagai perempuan tangsi yang berperilaku layaknya perempuan bangsawan. Seperti pujian Shakespeare terhadap perempuan dalam naskah drama King Lear (2004:123) "Suaranya lembut, kalem dan lemah, sebuah hak yang menakjubkan pada diri perempuan".

Teyi sebagai orang Timur memiliki salah satu ciri orang Timur yang diutarakan Poespowardojo (1989: 108), yaitu memiliki kemampuan adaptasi yang tinggi dengan keterbukaan menerima budaya lain. Dalam Gadis Tangsi, Teyi dapat dikatakan sebagai individu yang supel, cerdas, bersifat terbuka, dan mau menerima perubahan, sehingga ia dapat dengan cepat menerima apa yang diajarkan Putri Parasi.
Teyi dapat diilustrasikan seperti seorang gadis desa yang bermimpi menjadi putri dan mimpinya tersebut terwujud dengan usaha dan kerja kerasnya serta adanya peluang yang terbuka lebar. Hubungannnya dengan kedua perempuan, Raminem dan Putri Parasi, menjadi peluang baginya untuk menggapai mimpi.

Obsesinya untuk menjadi putri bangsawan terbentuk dengan pola yang dibuat Putri Parasi. Stereotip positif tentang Keraton Jawa yang adiluhung dan perempuan bangsawan yang berkelas lebih tinggi sehingga mendapatkan perlakuan yang berbeda dari Belanda dan stereotip negatif tentang perempuan tangsi membentuk keinginan Teyi untuk masuk dalam kelompok bangsawan. Ia dengan giat belajar tentang kehidupan bangsawan Jawa dan terobsesi untuk menikah dengan laki-laki bangsawan agar derajatnya sebagai perempuan meningkat.

\section{SIMPULAN}

Hubungan antara anak perempuan dengan ibunya (daughterhood) digambarkan dalam novel Gadis Tangsi karya Suparto Brata. Dalam novel tersebut Teyi memiliki hubungan sangat erat dengan Raminem ibunya dan dengan Putri Parasi, guru sekaligus ibu keduanya. Hubungan tersebut telah membentuk identitas Teyi menjadi seorang gadis tangsi yang cerdas, cantik, elegan, berani.

Raminem mendidik Teyi dengan keras agar menjadi perempuan yang mandiri dan tidak malas mencari uang. Cara mendidik Raminem dilandasi oleh semangatnya untuk menjadi orang kaya. Teyi mendapatkan tekanan dari ibunya untuk membantu mencapai impiannya itu dengan berjualan pisang goreng keliling tangsi. Berjualan pisang goreng keliling tangsi telah membuka peluang 
bagi Teyi. Ia berinteraksi dengan setiap orang di lingkungan tangsi, terutama saat mereka membeli pisang gorengnya. Kegiatannya itu membuka peluang bagi Teyi untuk bertandang ke rumah Putri Parasi dan berinteraksi langsung dengannya.

Berbeda dengan Raminem yang mendidik secara kasar, Putri Parasi justru mendidik Teyi dengan lembut dan mengikuti keinginan Teyi, tanpa paksaan sedikit pun. Ia mengajarkan Teyi tentang cara bersikap dan berperilaku seperti perempuan bangsawan, berbahasa kromo inggil, dan berbahasa Belanda. Selain itu, Putri Parasi membentuk Teyi untuk menjadi perempuan bangsawan sehingga dapat menikah dengan lakilaki bangsawan.

Hubungan antara anak perempuan dengan ibunya itu berhasil membentuk identitas Teyi menjadi gadis tangsi yang berbeda dengan gadis tangsi lainnya. Teyi telah menaikkan derajat identitasnya menjadi sejajar seperti bangsawan. Ia dapat bergaul dengan kelompok kelas sosial yang lebih tinggi di tangsi tersebut. Ia berbahasa Belanda ketika bergaul dengan orang Belanda dan berkromo inggil dengan laki-laki bangsawan. Teyi telah terbentuk menjadi perempuan yang mandiri, berani, tetapi juga mampu bersikap dan berperilaku seperti bangsawan.

\section{UCAPAN TERIMA KASIH}

Artikel ini diangkat dari penelitian mandiri swadana yang dilaksanakan pada tahun 2010. Ucapan terima kasih disampaikan kepada para mahasiswa yang telah membantu pelakasanan pengumpulan data dan kepada mitra sejawat yang telah membantu kegiatan verifikasi dan triangulasi data dan hasil penelitian

\section{DAFTAR PUSTAKA}

Poespowardojo, Soerjanto. 1989. Strategi Kebudayaan Suatu Pendekatan Filosofis. Jakarta: PT Gramedia.

Pusat Bahasa Depdiknas. 2002. Kamus Besar Bahasa Indonesia. Jakarta: Balai Pustaka.

Redaksi Jurnal Perempuan. "Kata dan Makna". Jurnal Perempuan Edisi 16.

Shakespeare, William. 2004. King Lear (terjemahan). Yogyakarta: Celepuk.

Susetyo, DP. Budi. 2002. "Krisis Identitas Etnis Cina di Indonesia". www. unika.ac.id. 


\title{
BENTUK-BENTUK POSKOLONIALITAS DI INDONESIA MUTAKHIR PADA MAJALAH TEMPO
}

\author{
Oleh \\ Nurhadi, Iman Santoso, Dian Swandayani, dan Ari Nurhayati \\ Fakultas Bahasa dan Seni Universitas Negeri Yogyakarta \\ email: nurhadi@uny.ac.id
}

\begin{abstract}
This article presents two points, i.e. postcolonial forms and patterns in Tempo, especially those in the section of literary book reviews. The study focused on the literary book reviews in Tempo published in 2000 - 2007. The data were collected through document analysis and were analyzed using the content analysis and qualitative descriptive technique. The findings are as follows. First, postcolonial themes in some literary book reviews in Tempo talk about: (1) stories of the Orient, (2) colonialism, (3) reviews of Western literature (including works translated into Indonesian), and (4) literary works talking about postcolonial matters. Besides, some reviews are related to: (5) Indonesian literature translated into English, (6) the encounter of the West and the East in several stories, and (7) Islam in the West. Second, the reviewers are aware of postcolonial patterns in the form of literary book reviews.
\end{abstract}

Keywords: postcoloniality forms, postcoloniality patterns, Western, domination

\section{PENDAHULUAN}

Sebagian besar perguruan tinggi di Indonesia memiliki program studi bahasa asing, khususnya bahasa Inggris. Selain itu ada sejumlah universitas, institut, ataupun akademi yang memiliki program studi bahasa asing lainnya seperti bahasa Perancis, Jerman, Belanda, Rusia, ataupun Italia. Pembelajaran bahasa asing di perguruan tinggi atau universitas seringkali menjadi kepanjangan tangan kepentingan negara Barat. Baik mahasiswa ataupun dosen bahasa Inggris seringkali mewakili identitas dan kepentingan Inggris daripada menjadi orang Indonesia.

Mahasiswa dan dosen bahasa Perancis seringkali menandai identitas kulinernya dengan memilih makanan bercita rasa Eropa (Perancis) sehingga mereka lebih memilih menikmati keju ataupun yogurt daripada makanan ketela. Mereka lebih menikmati lagu- lagu berbahasa Perancis dan lebih memilih film-film yang menang dalam Festival Film Canes daripada film-film negeri sendiri. Sikap dan tindakan semacam itu tanpa disadari merupakan bentuk kepanjangan tangan dari bangsa asal bahasa asing itu dipelajari. Para mahasiswa itu seringkali lebih bersikap Inggris daripada orang Inggris itu sendiri. Mereka lebih Perancis daripada orang Perancis itu sendiri. Demikian pula pada kasus pembelajaran bahasa asing (Barat) lainnya.

Yang lebih berbahaya apabila para mahasiswa (agen perubahan setiap bangsa) Indonesia terlena dengan selalu beranggapan jika Indonesia selalu berada dalam posisi subordinat dibandingkan dengan negara asal bahasa yang tengah dipelajarinya. Mereka tidak lagi menyadari kalau bahasa asing target yang dipelajarinya hanya sebatas media untuk menyerap berbagai 
aspek IPTEKS negara asal untuk kepentingan Indonesia, bukan kepanjangan tangan poskolonial. Inilah sindrom poskolonial. Meskipun Indonesia secara de fakto telah merdeka, ada berbagai aspek yang menunjukkan pengukuhan (pengakuan atau legitimasi) dan peniruan (mimikri) terhadap aspek-aspek yang berasal dari Barat sebagai bekas penjajah. Hal inilah yang harus disadari secara kritis.

Oleh karena itu, perlu adanya penelitian terhadap aspek-aspek poskolonial dalam pembelajaran bahasa asing (Barat) di Indonesia. Untuk mengetahui hal tersebut perlu pengkajian terhadap pemakaian text book (buku ajar) yang dipergunakan dalam pembelajaran bahasa asing (Barat) tersebut dan buku-buku referensinya, baik berupa karya sastra maupun pemikiran (filsafat) Barat.

Artikel ini berusaha mengungkap fenomena posolonial mutakhir dalam bidang pembelajaran bahasa asing (Barat) yang merupakan salah satu bidang kajian IPTEKS khususnya bidang seni budaya. Seperti dikemukakan di depan, budaya Eropa sebagai bekas negara penjajah seringkali dijadikan trendsetter bagi Indonesia apalagi dalam dunia yang berkembang sangat cepat dalam era digital dan virtual seperti yang diungkapkan Piliang (1998:1-35) dalam Dunia yang Dilipat. Seberapa jauh pandangan poskolonial Barat (Eropa dan Amerika) masih mengakar dalam bentuk pembelajaran bahasa asing melalui text book yang dipergunakan dan sejumlah referensi lainnya yang berupa karyakarya sastra Barat terjemahan ataupun buku filsafat Barat terjemahan.

Sebagaimana dikemukakan oleh Williams (1988:88-93), karya sastra, filsafat, buku ajar (pelajaran), karya seni, sekolah, dan institusi budaya lainnya merupakan situs hegemoni, yakni tempat pertarungan ideologi berlangsung. Sebagaimana dipahami oleh pandangan Gramscian, karya sastra, buku filsafat, ataupun buku-buku pegangan di universitas (sebagai objek kajian penelitian ini) merupakan tempat refleksi pandangan dunia masyarakat pendukungnya, tetapi sekaligus juga sebagai medium untuk mengkonstruksi masyarakat. Sebuah pandangan dunia, ideologi ataupun gaya hidup masyarakat seringkali dikonstruksi oleh situssitus hegemoni yang disebarkan melalui sejumlah institusi hegemoni seperti sekolah, media massa, gereja, dakwahdakwah keagamaan, dan lain sebagainya. Dalam proses pertarungan ideologis inilah, bentuk-bentuk poskolonialisme di Indonesia akan dianalisis lewat sejumlah media cetak yang beredar di Indonesia tempat sejumlah karya sastra Barat dan buku-buku pemikiran Barat diresensi atau diulas. Selain itu, juga akan dianalisis sejumlah text book bahasa asing yang dipergunakan di sejumlah universitas di Indonesia.

Proses akulturasi budaya Barat (Eropa dan Amerika) seringkali tanpa disadari akan masuk dalam perangkap poskolonial yang melanggengkan dominasi nilai-nilai Eropa atas nasionalisme Indonesia. Sebagaimana dinyatakan oleh Anderson (2002:1-15), nasionalisme merupakan komunitas imajiner yang harus dikonstruksi dan dipertahankan oleh para pendukungnya. Dalam konstelasi nasionalisme Indonesia tersebut, bentuk-bentuk poskolonialisme Barat (sebagai negara dominan) harus dicermati secara kritis sehingga tidak terperangkap praktik imperialisme Barat model baru.

Studi poskolonial di Barat salah satunya ditandai dengan kemunculan buku Orientalisme (1978) karya Edward Said yang kemudian disusul dengan sejumlah buku lainnya yang masih 
terkait dengan perspektif Barat dalam memandang Timur. Buku-buku Said seperti Covering Islam: How the Media and the Experts Determine How We See the Rest of the World (1981) dan Culture and Imperialism (1993) merupakan sekuel dari buku Orientalisme tersebut. Buku semacam The Empire Writes Back (1989) suntingan Bill Ashcroft, Gareth Griffiths, dan Helen Tiffin merupakan buku lain yang sering dijadikan rujukan dalam pembahasan teori poskolonial.

Teori poskolonial itu sendiri merupakan sebuah seperangkat teori dalam bidang filsafat, film, sastra, dan bidang-bidang lain yang mengkaji legalitas budaya yang terkait dengan peran kolonial. Bidang ini bukanlah menjadi monopoli kajian sastra. Poskolonial mirip dengan kajian feminisme yang meliputi bidang kajian humaniora yang lebih luas; sejajar dengan kajian posmodern atau postrukturalisme.

Pada paruh akhir abad ke-20, selain strukturalisme yang mengkaji karya sastra hanya berdasarkan strukturnya, ada juga sejumlah kajian atau teori sastra yang melibatkan unsur kesejarahannya dan konteks sosialnya. Teori-teori seperti cultural studies, new historisisme, dan poskolonial untuk sekedar menyebut contoh merupakan kajian-kajian sastra yang menganalisis karya sastra dalam konteks kesejarahannya ataupun konteks sosialnya. Poskolonial merupakan kajian terhadap karya-karya sastra (dan bidang yang lain) yang berkaitan dengan praktik kolonialisme atau imperialisme baik secara sinkronik maupun diakronik. Kajian poskolonial berusaha membongkar selubung praktik kolonialisme di balik sejumlah karya sastra sebagai superstruktur dari suatu kekuasaan, kekuasaan kolonial. Sastra dipandang memiliki kekuatan baik sebagai pembentuk hegemoni kekuasan atau sebaliknya sebagai konter hegemoni.
Seperti yang diungkap Said dalam Orientalisme, ada sejumlah karya sastra dalam dunia Barat yang turut memperkuat hegemoni Barat dalam memandang Timur (Orient). Sejumlah karya seni itu telah melegitimasi praktik kolonialisme bangsa Barat atas kebiadaban Timur. Penjajahan adalah sesuatu yang alamiah, bahkan semacam tugas bagi Barat untuk memberadabkan bangsa Timur. Kajian Said ini memang berangkat dari teori hegemoni Gramscian dan teori diskursus Foucaultian. Kata "post" yang dilekatkan dengan kata "colonial" sebetulnya kurang tepat kalau diindonesiakan menjadi "pasca". Kasus ini mirip dengan pengindonesiaan kata "discourse" dalam istilah Foucault (Rogers, 2007) yang tidak sama persis maknanya dengan kata "wacana". Ada kekhususan.

Kata pascakolonial yang seringkali dijadikan terjemahan dari postcolonial merupakan istilah yang mengacu pada permasalah "waktu setelah" kolonial. Padahal poskolonial tidak hanya mengacu pada kajian sastra sesudah masa era penjajahan, atau era kemerdekaan tetapi lebih luas mengacu pada segala yang terkait dengan kolonialisme yang pada abad ke-21 hanya menyisakan Amerika sebagai bangsa penjajah yang kesiangan. Konteks poskolonialisme juga mencakup kasus globalisasi dan perdagangan bebas yang seringkali dianggap sebagai bentuk neokolonialisme. Kata post sebaiknya diartikan sebagai "melampaui" sehingga poskolonial adalah kajian yang melampaui kolonialisme, artinya bisa berupa pasca atau permasalahan lain yang masih terkait meskipun tampak seperti terpisah dari kolonialisme.

Jangkauan luarbiasaimperialisme Barat pada abad ke-19 dan awal abad ke-20 merupakan salah satu fakta yang paling menakjubkan dalam sejarah politik. Melalui penafsirannya yang 
yang brilian atas kanon-kanon Barat seperti Heart of Darkness (karya Conrad), Mansfield Park (karya Austen), dan Aida (komposisi musik karya Verdi), Said (1994:259) menunjukkan bagaimana kebudayaan dan politik bekerja sama. Sebuah konsep dasar yang dipaparkan pemikir Komunis Italia, Antonio Gramsci tentang hegemoni yang menyatakan bahwa kekuasaan terbangun atas dominasi (senjata) dan hegemoni (kebudayaan).

Menurut Said (2002:ix) kebudayaan dan politik pada kasus kolonialisme telah bekerja sama, secara sengaja ataupuntidak, melahirkan suatu sistem dominasi yang melibatkan bukan hanya meriam dan serdadu tetapi suatu kedaulatan yang melampaui bentuk-bentuk, kiasan dan imajinasi penguasa dan yang dikuasai. Hasilnya adalah suatu visi yang menegaskan bahwa bangsa Eropa bukan hanya berhak, melainkan wajib untuk berkuasa. Argumen utama dosen kritik sastra Universitas Columbia AS ini adalah bahwa kekuasaan imperial Barat selalu menemui perlawanan terhadap imperium. Lelaki keturunan Palestina ini menelaah kesalingketergantungan wilayah-wilayah kultural tempat kaum penjajah dan terjajah hidup bersama dan saling berperang, dan melacak kisah-kisah "perlawanan" dalam diri para penulis poskolonial seperti Fanon, C.L.R. James, Yeats, Chinua Achebe, dan Salman Rusdhie.

Dalamduniaposkolonialsekarang ini, Said (1995:28) mengajukan sanggahan terhadap argumen-argumen yang mengatakan bahwa kebudayaan dan identitas nasional adalah entitas-entitas yang tunggal dan murni seperti yang dipaparkannya dalam buku Culture and Imperialism (yang diindonesiakan oleh Penerbit Mizan menjadi Kebudayaan dan Kekuasaan). Dengan melucuti pengertian "kita" dan "mereka" dari imperium,
Said menunjukkan bagaimana asumsiasumsi imperialis yang busuk terus mempengaruhi politik dan kebudayaan Barat, sejak peliputan media atas Perang Teluk hingga pengajaran sejarah dan kesusastraan di sekolah-sekolah.

Apa yang dilakukan Said dalam sejumlah bukunya dalam menelanjangi praktik-praktik poskolonial tersebut selain berangkat dari teori hegemoni sebetulnya juga berawal dari konsep diskursus-nya Foucault seperti dalam bukunya Power/Knowledge (2002). Poskolonial merupakan sebuah kajian yang relatif luas dan baru. Apa sajakah yang menjadi cakupan pembicaraannya, siapa saja tokoh-tokohnya, dan pengarang manakah yang tergolong sebagai pengarang poskolonial? Informasi ini bisa dilihat dalam situs www. english.emory.edu. Dalam situs ini pula beberapa penulis seperti Bahri (2007) menuangkan gagasannya tentang "Introduction to Postcolonial Studies" ataupun Beya (2007) tentang "Mimicry, Ambivalence and Hybridity". Jurnal internasional tentang poskolonial juga telah diterbitkan, yakni Journal Postcolonial Text yang edisi terakhirnya membahas peran Afrika dalam konteks poskolonial dan tentang On Things Fall Apart dari berbagai perspektif poskolonial (Esonwanne, 2009).

Berdasarkan penelesuran pada kedua sumber poskolonial tersebut, tampaknya sejumlah tema dan tokohtokoh poskolonial malah diproduksi dan direproduksi dalam bahasa Inggris atau Perancis yang notabene adalah bahasa kolonial. Meski demikian, sejumlah buku poskolonial telah banyak diterjemahkan dalam bahasa Indonesia. Selain buku-buku Edward Said, bukubuku poskolonial lain yang telah diterjemahkan ke dalam bahasa Indonesia misalnya karya Gandhi (Teori Poskolonial, Upaya Meruntuhkan Hegemoni 
Barat, 2001), Loomba (Kolonialismel Pascakolonialisme, 2003, Aschroft dkk (Menelanjangi Kuasa Bahasa: Teori dan Praktik Sastra Poskolonial, 2003). Selain itu ada sejumlah penulis Indonesia yang juga menerbitkan buku dengan topik poskolonialisme, salah satunya Faruk dengan bukunya yang berjudul Belenggu Pasca-Kolonial (2007) dan Muhidin M. Dahlan (penyunting) dengan judul Postkolonial Sikap Kita terhadap Imperialisme (2001).

Dalam buku The Empire Writes Back (1989) suntingan Bill Ashcroft, Gareth Griffiths, dan Helen Tiffin (yang diindonesiakan Penerbit Qalam menjadi Menelanjangi Kuasa Bahasa, 2003) terdapat sejumlah tema-tema terkait dengan kajian poskolonial ini. Selain buku ini, ketiga penulis ini juga mengeditori sebuah buku yang sering dijadikan rujukan meski belum diterjemahkan dalam bahasa Indonesia, yakni The Postcolonial Studies Reader (1995). Adapun dalam The Empire Writes Back setidaknya dua hal yang dilakukan dalam buku ini yaitu: (1) mengindentifikasi cakupan dan sifat-sifat dasar teksteks poskolonial; (2) mendeskripsikan beragam teori yang hingga kini telah banyak muncul untuk menjelaskannya.

\section{METODE}

Objek penelitian ini adalah artikelartikel resensi buku (khususnya terhadap buku-buku karya sastra Barat) yang dimuat di media cetak utama Indonesia: Tempo (majalah umum mingguan) edisi tahun 2000-2007. Untuk penelitian ini akan dilakukan pendokumentasian atau studi pustaka dan analisis isi terhadap objek penelitian ini.

Teknik pengumpulan data dilakukan dengan teknik studi dokumentasi terhadap sejumlah artikel resensi buku sastra Barat di media cetak, dalam konteks ini majalah Tempo, khususnya rubrik "Buku". Teknik analisis datanya yaitu dengan analisis konten dan deskriptif kualitatif. Analisis konten dilakukan dalam menganalisis isi artikel resensi dari media cetak Indonesia (majalah Tempo) sehingga akan diperoleh gambaran yang menyeluruh dan utuh atas bentuk-bentuk poskolonial. Analisis deskriptif kuantitatif dipergunakan dalam menafsirkan temuan-temuan tersebut.

Validitas dan reliabilitas data dicapai dengan beberapa teknik, yakni: (1) validitas semantis, (2) reliabilitas intrarater, dan (3) diskusi antarpeneliti atau reliabilitas interrater.

\section{HASIL DAN PEMBAHASAN}

Penelitian pada majalah Tempo lebih difokuskan pada rubrik resensi buku sastra. Dari jumlah 8 bundel (edisi tahun 2000-2007) terdapat sekitar 416 artikel resensi buku (dengan rata-rata satu edisi satu artikel resensi buku, karena kadang-kadang satu edisi ada yang tidak memuat resensi buku atau kadang-kadang malah memuat dua artikel) yang kemudian disortir khusus untuk resensi buku sastra jumlahnya menjadi 169. Dari jumlah inilah kemudian dipilah lagi dengan memfokuskan pada artikel-artikel resensi buku yang terkait dengan tema poskolonialitas.

Pada majalah Tempo, tema-tema poskolonialitas muncul pada sejumlah artikel resensi sastra yang membahas: (1) kisah-kisah tentang Timur, (2) tentang penjajahan, (3) ulasan sastra Barat (termasuk yang diterjemahkan ke dalam bahasa Indonesia), (4) karya-karya sastra yang secara khusus membahas permasalahan poskolonial. Selain hal-hal tersebut, kajian ini juga meliputi hal-hal yang terkait dengan: (5) sastra Indonesia yang diterbitkan (diterjemahkan) dalam bahasa Inggris, (6) pertemuan Barat dan Timur dalam berbagai kisah, (7) Islam di Barat. 


\section{Bentuk-bentuk Poskolonialitas pada Majalah Tempo}

Kisah-kisah Timur dengan kaca mata Barat muncul dalam sejumlah karya sastra yang kemudian tampil dalam sejumlah resensi. Buku The Spice Garden yang ditulis oleh Michael Vatikiotis lebih banyak berkisah tentang kejadian di Indonesia khususnya di Maluku (Tempo, 01-07 Maret 2004). Terhadap buku ini, Dewi Anggraini menyatakan bahwa rentetan sengketa berdarah yang terjadi di Maluku sejak 1999 terekam di koran dan majalah, televisi dan radio. Tapi semua itu begitu singkat mendekam pada kesadaran kita. Dan Michael Vatikiotis "menjaring" kita ke dalam peristiwa mengerikan di Maluku itu cukup dengan cara virtual. Novelnya, The Spice Garden, meluncurkan kita ke sebuah pulau fiktif tidak begitu jauh dari Ambon, pada masa yang sangat tidak fiktif, masa-masa berdarah 1999. Gambaran semacam ini menarik untuk dicermati, karena bukan tidak mungkin bahwa Indonesia (Timur) seringkali muncul dalam bentuk negara yang penuh dengan kekerasan, kekacauan, dan amuk.

Gambaran Indonesia dari sudut orang-orang Barat atau ekspatriat sebelumnya telah muncul dalam ulasan Tempo pada edisi 26 Maret-1 April 2001. Buku-buku fiksi ini kebanyakan berkisah tentang Indonesia dengan latar politik yang seringkali dipandang sebagai kawasan yang eksotik, sebuah wilayah baru yang selalu menarik perhatian para pengelana. Jika buku ini membahas Indonesia mutakhir, ada buku lain yang meneropong sejarah Indonesia pada masa sejarahnya dari kacamata orang-orang Perancis.

Buku yang berjudul Orang Indonesia dan Orang Perancis dari Abad XVI sampai dengan Abad XX yang ditulis oleh Bernard Dorleans dikomentari oleh Jean Couteau (orang Perancis yang mengajar di Denpasar) pada Tempo edisi 11-17 Desember 2006. Dalam buku ini tampak bagaimana orang-orang Indonesia dipersepsi oleh orang-orang Perancis sebagai orang-orang dianggap primitif dan tidak berbudaya. Tentu saja gambaran semacam itu menjadi gambaran yang khas ketika Barat yang merasa superior memadang orang-orang Timur yang inferior. Gambaran semacam itu diungkap kembali oleh penulis resensi dengan mengutip salah satu tulisan yang dikumpulkan dan dieditori oleh Bernard Dorleans. Salah satunya sebagai berikut.

ORANG-ORANG pribumi berperawakan cukup tinggi, beberapa di antaranya bertubuh sempurna sedangkan yang lain tidak. Mereka tak sehitam orang Guinea, hidungnya pun tak sepesek mereka. Mereka berkulit kuning atau cokelat, penipu dan pembohong besar."

Penjelajah Perancis Francois de Vitré menggambarkan orang Sumatra dalam tulisannya pada 1602. Tiga ratus tahun kemudian, Cabaton, penjelajah Perancis yang lain menulis dengan nada yang sama terhadap orang Jawa. "Orang-orang Jawa bukan pekerja, cukup segenggam nasi dan beberapa buah untuk hidup yang mereka dapatkan tanpa usaha. Semua itu mereka peroleh hanya karena kesuburan tanah saja...."

Tampaknya, Jean Couteau sebagai penulis resensi menyadari akan adanya bias perspektif kolonial manakala mengulas buku ini. Hal tersebut muncul dalam tulisannya pada bagian lain yang menyatakan bahwa pertemuan-pertemuan antara figur Perancis dan "Indonesia" di buku ini tak lebih sebagai kumpulan fakta dan data yang amat 
miskin unsur empatinya. Tak tergambarkan kisah pertemuan antarmanusia. Tak terlihat nada haru persahabatan ataupun cinta.

Selanjutnya dia menyatakan bahwa yang mengemuka dalam buku ini justru sindiran, penolakan, dan vonis atas perilaku "kaum pribumi", atau sebaliknya, informasi yang nyata-nyata didasari oleh kepentingan pragmatis. Seolah-olah orang Perancis dan Indonesia hanya terkait satu sama lainnya melalui jaringan kepentingan, nyaris tanpa faktor kemanusiaan sama sekali. Seolah-olah hubungan antara orang "Indonesia" dan "Barat" sepenuhnya digenangi kepentingan ekspansi imperial, lengkap dengan segala kesalahpahamannya. Inilah stereotip kenaifan yang disuguhkan Dorleans.

Lebih lanjut penulis resensi menyatakan bahwa pilihan judul buku juga patut dipertanyakan. Seolah yang hendak digambarkan ialah tak kurang dari empat abad hubungan antara orang Indonesia dan orang Perancis! Lebihlebih dengan menampilkan orang Indonesia lebih awal pada judul, tersirat kesan bahwa sudut pandang Indonesialah yang utama, padahal yang terjadi orang Indonesia hanya obyek semata (dalam edisi bahasa aslinya, kata "Perancis" disebut lebih dulu daripada kata "Indonesia").

Gambaran seperti dalam buku Orang Indonesia dan Orang Perancis dari Abad XVI sampai dengan Abad XX yang lebih menekankan pada aspek faktualnya daripada aspek fiksinya lebih menggambarkan bagaimana Barat dalam memandang Timur. Gambaran inferioritas terhadap bangsa Timur juga muncul dalam sejumlah aspek meskipun tidak tampak secara eksplisit. Gambaran Timur yang inferioritas seringkali muncul dalam berbagai buku fiksi (maupun yang semi-fiktif) manakala orang-orang
Barat menulis dan mendeskripsikan tentang orang-orang Indonesia atau keadaan alamnya.

Buku-buku seperti Kuasa Kata: Jelajah Budaya-budaya Politik di Indonesia oleh Benedict Anderson (Tempo, 19-25 Maret 2001), Surat-surat Adik RA Kartini yang dieditori oleh Frits G.P. Jaquet (Tempo, 20-26 Juni 2005), buku Sumber Terpilih Sejarah Sastra Indonesia Abad XX oleh Ulrich Kratz (Tempo, 27 Maret-2 April 2000), buku Amin Sweeney tentang biografi dan bibliografi Abdullah bin Abdul Kadir Munsyi (Tempo, 1-7 Agustus 2005), buku tentang Kitab Melayu Tertua oleh Ulrich Kozok (Tempo, 713 Agustus 2006) seringkali tanpa terasa memunculkan pandangan tentang Indonesia yang perlu dipelajari atau dipahami. Hal ini merupakan kelanjutan dari apa yang sebelumnya sering dinamakan dengan kajian orientalisme.

Kajian orientalisme secara khusus sebenarnya muncul dalam diri Prof P.J. Zoetmulder yang banyak meneliti tentang karya-karya sastra Jawa. Dalam Tempo edisi 20-26 Februari 2006 dimuat informasi tentang biografi ilmuwan asal Belanda yang kemudian menjadi WNI ini dalam kiprahnya menyingkap dan mewartakan kesusastraan Jawa. Apa yang dilakukan oleh tokoh semacam Zoetmulder seringkali dikaitkan dengan kajian orientalisme, entah terkait secara langsung ataupun tidak terhadap praktik kolonialisasi yang memayunginya.

Jika Zoetmulder mengkoleksi dan menganalisis naskah-naskah Jawa Kuno, tampaknya ada seorang Belanda yang relatif sama dalam mengoleksi buku-buku Indonesia. Jaap Erkelens mencari dan mengoleksi buku-buku Indonesia untuk kepentingan KITLV Belanda. Tindakannya merupakan usaha untuk mengumpulkan informasi tentang Indonesia. Hal ini tergambar dalam Tempo edisi 11-17 Agustus 2003. 
Selain gambaran Timur lewat kacamata atau kepentingan Barat, aspek poskolonialitas lainnya yang muncul adalah gambaran sejarah penjajahan yang ditulis dalam konteks kekinian. Artinya, proses penjajahan yang telah berlalu itu kemudian dibicarakan dan diulas kembali dalam sejumlah buku. Inilah yang dinamakan reproduksi terhadap kisah-kisah kolonialitas lewat karya sastra.

Salah satu buku yang menghidupkan kembali peristiwa kolonialisasi di Indonesia adalah Jalan Raya Pos, Jalan Deandels karya Pramoedya Ananta Toer yang diterbitkan tahun 2005. Buku ini diresensi oleh Nurdin Kalim dan Evieta Fadjar yang dimuat dalam Tempo edisi 17-23 Oktober 2005. Tentu saja, pandangan pembuatan jalan pada masa Deandels ini sebagai gambaran pilu praktik penjajahan. Tulisan semacam ini, baik pada buku Pramoedya itu sendiri maupun tulisan resensinya, adalah bentuk reproduksi kisah kelam penjajahan, bukan nostalgia yang membahagiakan. Pramoedya adalah anak negeri yang dalam biografinya turut menentang penjajahan kembali Belanda. Perhatikan kutipan resensi yang juga kutipan dari buku ini.

MATI. Mereka meninggal karena kelaparan, kelelahan, atau terserang penyakit. Yang membangkang digantung di pepohonan di sepanjang ruas jalan.

Inilah kisah pembangunan jalan sepanjang 1.000 kilometer, dari Anyer di Jawa Barat hingga Panarukan di Jawa Timur. Kisah yang berawal dari imajinasi seorang Gubernur Hindia Belanda, dalam perjalanannya dari Buitenzorg atau Bogor ke Semarang dan Oesthoek alias Jawa Timur. Dalam bukunya yang terakhir, Jalan Raya Pos, Jalan Daendels, Pramoedya Ananta Toer mencatat perjalanan itu tertanggal 29 April 1808, dan si pe- milik imajinasi itu adalah Herman Willem Daendels.

Imajinasi yang cepat menjadi ambisi buta. Ya, proyek raksasa itu menggunakan kerja rodi, tanpa bayar-kalaupun ada, upahnya sudah disunat oleh mandor baik berkulit putih maupun cokelat, atau keduanya, tulis Pramoedya. Korban semakin banyak, "ribuan orang kecil di Grobogan, wilayah Keresidenan Semarang, berkaparan tak terkuburkan," tutur Pram (hlm. 22). Tapi angan-angan sang Gubernur Jenderal tak kunjung kendur.

Kisah kelam praktik penjajahan juga muncul pada buku Pramoedya lainnya yang terbit pada 2001, berjudul Cerita dari Digul, yakni tempat pembuangan para pemberontak pada kolonial Belanda di wilayah Papua. Resensi tentang buku ini ditulis oleh Wilson di Tempo edisi 25 Juni-1 Juli 2001. Cerita tentang Digul juga ditampilkan dalam buku Marco Kartodikromo yang berjudul Pergaulan Orang Buangan di Boven Digul: Kisah Nyata yang aslinya berupa cerita bersambung di surat kabar Pewarta Deli dari 10 Oktober sampai 9 Desember 1931. Buku ini diulas oleh M. Fauzi pada Tempo, 26 Mei-01 Juni 2003. Gambaran masa penjajahan Belanda dari orangorang nasionalis seperti Marco ataupun Pramoedya merupakan gambaran negatif tentang masa itu yang seringkali juga terkait dengan masa kini, ketika orangorang menyebutnya sebagai masa poskolonial.

Jejak hitam kolonialisme muncul dalam karya-karya masa kini sebagai bentuk reproduksi terhadap wacana tentang kolonial juga diberitakan oleh Tempo edisi 19-25 September 2005 dalam tiga artikel berturut-turut untuk rubrik buku. Ketiga artikel tersebut sebetulnya terkait tentang komik tetapi juga memiliki kaitan dengan sejarah penjajahan Belanda. Ketiga artikel itu berjudul 
"Bila Sang Meneer Melukis Indonesia", "Menunggu Komik Asli Indonesia", dan "Membuka Jejak Hitam Kolonial".

Meski demikian, ada juga penulisan penggalan sejarah kolonial ini dalam suasana yang lebih menekankan kepada aspek nostalgia, sebuah kenangan yang menyisakan keindahan seperti pada Tempo edisi 08-15 Agustus 2004 yang berjudul "Potret dari Jejak Masa Lalu". Buku yang diulas majalah Tempo kali ini hanya memuat lima cerita pendek karya Made Sanggra, seorang pegiat sastra Bali yang sudah berusia lanjut. Kelima cerpen itu adalah "Tukang Gambar" (1970), "Kucit" (1970), "Sekar Emas" (1970), "Katemu ring Tampaksiring" (1972), dan "Suaran Asu" (1972). Karena dianggap karya terbaiknya, kelima cerpen itu diterbitkan dengan terjemahan dalam bahasa Indonesia dan Inggris.

Salah satu cerpen dari buku ini terkait dengan rencana Ratu Juliana dari Belanda yang akan berkunjung ke Istana Tampaksiring di Gianyar, Bali. Ratu yang belum pernah ke Bali itu rencananya bakal berkunjung pada tahun 1970. Made Sanggra, seorang pejuang Bali, ingin menyampaikan rasa persahabatan kepada sang Ratu dari negara yang pernah menjajah bangsa ini. Maka, ia pun menulis cerita pendek dalam bahasa Bali, "Katemu ring Tampaksiring".

Karena Ratu Juliana tidak jadi datang, cerpen itu juga tidak selesai. Made Sanggra sempat melupakan idenya dan menulis cerita lain. Diantaranya cerpen berjudul "Tukang Gambar" ("Pelukis") dan sebuah puisi modern berbahasa Bali: "Suara Saking Setra" ("Suara dari Kuburan"). Kedua karya ini berhasil menjadi juara pertama lomba penulisan sastra Bali yang diadakan Majelis Pertimbangan dan Pembinaan Kebudayaan (Listibiya) Bali pada 1970. Ini mendorong Made Sanggra melanjutkan penulisan cerpen "Katemu ring Tam- paksiring". Cerpen itu diikutsertakan dalam lomba pada 1972 dan kembali merebut gelar juara pertama.

Salah satu bentuk "penjajahan" lain yang mungkin tidak bisa dikategorikan penjajahan ringan adalah bentuk-bentuk peninggalan atau pengaruh dari bangsa Barat terhadap Indonesia. Bentuk "penjajahan lain" itu berupa pengaruh budaya Portugis di Indonesia dalam bidang kebudayaan yang ditulis oleh Antonio Pinto da Franca. Buku ini diresensi oleh Ign. Haryanto (Tempo, 1218 Maret 2001).

Bentuk lain dari tema poskolonialisme yaitu berupa ulasan bukubuku sastra terbitan Barat atau terjemahan Barat di Indonesia. Bentuk ini tidak bisa secara khusus dikategorikan sebagai tema superioritas Barat dan inferioritas Barat, tetapi lebih pada bentuk pengaruh peniruan atau mimikri dalam bersastra atau bergaya hidup. Selain itu juga bisa memunculkan praktik abrogasi dan apropriasi yang menampilkan pengaruh budaya dari segi pemakaian bahasa manakala penggunaan bahasa Inggris dianggap memiliki status sosial yang lebih tinggi, termasuk ketika mengkonsumsi karya sastranya.

Sejumlah karya sastra Barat yang telah diulas di majalah Tempo selama delapan tahun awal abad ke-21 ini antara lain sebagai berikut: (1) Interpreter of Maladies (Jhumpa Lahiri), (2) Berahi (Jean Baudrillard), (3) Kitab Lupa dan Gelak Tawa (Milan Kundera), (4) Sabda Zarathustra (F.W. Nietzsche), (5) Kekekalan (Milan Kundera), (6) Out of Place (Edward W. Said), (7) Eragon (Christopher Paolini), (8) The English Roses (Madonna), (9) Va' Dore Ti Porta Il Coure atau Pergilah ke Mana Hatimu Membawamu (Susanna Tamaro), (10) Ikan Tanpa Salah (Alfred Birney).

Selain kesepuluh buku tersebut, masih ada lagi yaitu: (11) Insiden $A n-$ 
jing di Tengah Malam yang Bikin Penasaran (Mark Haddon), (12) Negeri Bahagia atau City of Joy (Dominique Lapierre), (13) Leo the African (Amin Maalouf), (14) The Dante Club (Matthew Pearl) (15) The Kid Runner (Khaled Hosseini), (16) Baudolino (Umberto Eco), (17) The Historian (Elizabeth Kostova), (18) Blindness (Jose Samarago), dan (19) Harry Potter and the Deathly Hollows (J.K. Rowling). Selain ulasan terhadap buku secara langsung, juga masih ada ulasan secara tidak langsung terhadap suatu peristiwa atau berita terkait buku lainnya seperti pada artikel yang berjudul "Sebuah Buku, Pesaing Harry Potter" yang membahas tentang buku The Da Vinci Code karya Dan Brown (Tempo, edisi 04 - 10 April 2005).

Selain itu, dari kesembilan belas daftar buku di atas, ada sejumlah buku sastra yang secara khusus juga mengangkat permasalahan poskolonialisme seperti: Interpreter of Maladies, Out of Place, Ikan Tanpa Salah, Negeri Bahagia atau City of Joy, Leo the African, dan The Kid Runner. Tema ini merupakan permasalahan yang dihadapi oleh tokoh-tokoh cerita yang mengalami perbenturan dalam kehidupan mereka yang berada di antara Barat dan Timur. Mereka mengalami ketercerabutan dari budaya asalnya. Tokoh-tokoh dalam karya sastra ini berkisah tentang manusia hibriditas ataupun manusia diaspora yang seringkali mengalami keterbelahan identitas atau kehilangan nasionalitasnya.

Dalam salah satu ulasan terhadap novel karya Alfred Birney, Ikan Tanpa Salah (De Onschuld van Een Vis), Nurdin Kalim mengulas problematika orangorang Indo (manusia hibriditas) sebagai berikut.

Darah campuran IndonesiaBelanda mengalir dalam tubuhnya. Ia pun terombang-ambing antara dua dunia dan penuh ketegangan akibat paradoks dalam dirinya. Malangnya, pribadinya lemah dan labil, tak pernah bisa bersikap. Ia tinggal di Nederland, tapi cara hidupnya Indonesia. Pola pikirnya tetap dibawa ke masa ketika ia masih di Indonesia sebagai perwira Belanda yang menginterogasi para pejuang Indonesia. Tubuhnya di Barat, jiwanya di Timur.

Dunia indo memang dunia simalakama. Mengutip Jakob Sumardjo, yang menulis pengantar novel ini, di luar kemampuannya, seorang indo terjebak dalam dunia yang saling bertentangan. Seorang Indo-Belanda bukan orang Belanda dan bukan orang Indonesia. Ia berada di mana? Berdiri sebagai orang Belanda, ia akan dicurigai dan dimusuhi orang Indonesia. Begitu pula sebaliknya. Posisi itu memunculkan sosok yang paradoks yang hidup dalam kegelisahan.

Itulah dunia poskolonialitas, khususnya bagi orang-orang hibriditas yang seringkali mengalami keterbelahan. Selain mengomentari tentang problematika yang dialami tokoh-tokoh novel ini, Nurdin Kalim (Tempo, 11.- 17 Oktober 2004) menyatakan komentar tentang penulisnya yang sejajar dengan penulis trans-nasional lainnya sebagai bentuk penghargaan keindoan Birney yang dekat dengan belahan Timurnya dibandingkan belahan Baratnya sebagaimana terdapat dalam kutipan berikut. "Novel ini menyejajarkan Birney dengan penulis transnasional lainnya seperti Salman Rushdie, yang menggambarkan India dari kediamannya di Inggris, atau Amy Tan, yang melukiskan Cina dengan warna Amerika. Penulis transnasional lebih cenderung menyuguhkan setting yang serba fragmented dan simbolis, tidak utuh dan realistis. Dari sisi ini, harus diakui Birney telah berhasil."

Selain permasalahan tema-tema poskolonialitas yang diangkat ke dalam tema-tema novel seperti yang dikemukakan di atas, yang merupakan bagian dari penerjemahan atau pengenalan 